JADEs: Journal of Academia in English Education

Volume 1 No 1, Juni 2020,(h.84-95)

https://journal.iainlangsa.ac.id/index.php/jades

\title{
Elizabethan Period \\ (The Golden Age of English Literature)
}

Ruly Adha

\begin{abstract}
English literature has been developed in some period. Each period has its own characteristics which portrayed the condition of the age. The period of English literature is started from Old English until Modern English. English literature becomes glorious when Queen Elizabeth I ruled England. This age is known as Elizabethan period. In this period, there are many literary works such as poetry, drama which are produced by famous artists. The literary works produced in Elizabethan period is famous and the existence of the literary works can be seen nowadays. Furthermore, some literary works, such as drama, are reproduced into movie. Therefore, this period is also known as the golden age of English Literature.
\end{abstract}

\section{A. Introduction}

According to Kamus Besar Bahasa Indonesia (2005), the word sastra has some meanings. Sastra can be defined as language (not daily language), words (figures of speech) used in a book. Besides, sastra also means Hindu's holy book, scientific books, or prophecies, and sastra also can be defined as writings or letters. Meanwhile, susastra is karya sastra yang isi dan bentuknya sangat serius berupa ungkapan pengalaman jiwa manusia yang ditimba dari kehidupan kemudian direka dan disusun dengan bahasa yang indah sebagai saranya sehingga mencapai syarat estetika yang tinggi (Kamus Besar Bahasa Indonesia, 20005). In other words, susastra means literary works which tell about human life experiences which are arranged in a good language and have an aesthetic value.

In English, the word sastra is called literature which means writings valued as works of art, writings on a particular subject, or printed material giving information (Oxford Dctionary, 2002). Manindranath Sinha (1991:1) says "Literature in the true sense of term is 
that kind of writing which is charged with human interest, and characterized by permanence, colouring of imagination, and artistic embellishment. It deals with the life of man and his destinies on earth. It expresses thoughts, feelings, emotions, and attitudes towards life, which are permanent and universal."

Human life experiences can be portrayed in any form of literary works such as poetry, drama, novel, etc. Those literary works develop as well as the development of civilization because literary works are the creation of human being and human being always develops every time. This condition can be seen in English Literature. English literature develops in some period. Every period has its own characteristics. Period of English literature are as follows:

1. Old English period

2. Middle English period

3. Elizabethan period / Renaissance period / Shakespearean period

4. Caroline period/ Puritan period / Milton period

5. Restoration period / Dryden period

6. Augustan period / Pope period

7. Romantic period

8. Victorian period

9. Modern period

From those period, Elizabethan period is regarded as the greatest development of English literature. The age of Elizabeth is characterized by abundance of production in branch of literature especially poetry and drama. The literary works of Elizabethan period are very famous and also can be found until now. Therefore, Elizabethan period is known as the golden age of English literature. 


\section{B. Discussion}

Elizabethan period started in 1550 until 1600. This period is called Elizabethan period because in that time England was ruled by the great Queen Elizabeth I. Queen Elizabeth I came to the throne in 1558 and ended in 1603. In the previous period, English literature has many rules which must be followed by the artists, so they cannot express their feeling freely because of the rules. In Elizabethan period, these rules have been left out. Therefore, the artists can express their feeling freely without being afraid to break the rules. As the result, there are so many literary works produced in this period. The artists seem to revive after binding by the rules. This period is also known as Renaissance period (Tilak, 1991:14).

Renaissance derives from Fench which means rebirth.Varshney (1990:1) says that renaissance was a transition from the middle ages to the modern world, and awakening from the darkness of the medieval period to the light and dawn of modern era. It was also a revolt against medieval dogma, against ecclesiastical tradition, against the authority of the church, against all the faltered free play of intellectual interests and impulses, against prejudice, routine, and stupidity.

Renaissance arose in Italy in $14^{\text {th }}$ century and began to spread out to other countries in the next century. Renaissance is characterized by the opening of human mind in Europe. In the middle age, people in Europe are bound by some rules made by church. The people must follow the rules and the traditions stated by the church. There is a punishment for everyone who does not want to follow the rules (Samekto, 1974:14). Renaissance succeeds to replace the authority of church with the authority of knowledge. The main characteristics of Renaissance people are individualistic and tend to secularism. They have freedom to express their feeling and also have strong feeling to find something new. When the Queen Elizabeth ruled England, the spirit of Renaissance became stronger 
in England. It gives an effect in literature. There are many literary works especially poetry and drama produced in this period. Therefore, this period is called the golden age of English literature.

Varshney (1990:2) says that there are some implications of renaissance in England. The implications are as follows:

1. The renaissance means rebirth, and the name refers to the rebirth of classical, especially Greek learning, after centuries of comparative neglect. It means the death of the medieval scholasticism which had for long been keeping human thought in bondage.

2. It is related to a questioning of tradition, the rise of a scientific spirit, emphasis on the complete development of the individual, and a concentration of attention on the present world rather than the next.

3. It was the birth of the modern world out of the ashes of the dark ages; the discovery of the world and the discovery of man, the era of untrammeled individualism in life, thought, religion and art.

4. The renaissance was a challenge to authority; the authority of church, of parents, of rules and regulations; it signalized the revolt against all kinds of authority.

5. The renaissance implied a perception of greater beauty and polish in the Greek and Latin scholars. This beauty and this polish were sought by renaissance men of letters to be incorporated in their native literature.

6. The renaissance stood for the birth and growth of humanism.

Therefore, it can be concluded that renaissance really gives the effect in English literature. There are many literary works produced in this 
period because of the effect. Some literary works produced in Elizabethan period can be seen in the following.

\section{Poetry}

The famous poet in this period is Edmund Spenser who was born in London in 1533. He finished his study in Cambridge in 1576. In 1594, he married Elizabeth Boyle and had four children. He died in 1599 at the age of 47. Edmund Spenser is known as the greatest poet of the age. His famous poem is the Faery Queen. Spenser starts to write a poem which consists of twelve parts which every part tells about the adventure of a knight. Spenser can only finish six parts from twelve parts that he planned before. In this poetry, Spenser invents the new stanza called Spenserian Stanza which consists of 9 lines. The rhyme of this stanza is a b- a - b - b - a - b - a - a (Samekto, 1974:15-16).

Spenser also writes another famous poem, namely Shepherd's Calendar. This poem consists of 12 lines which represents the months of a year. Shepherd's Calendar is a pastoral poem which tells about the life of shepherd.

\section{Drama}

From all literary works, drama is regarded as the greatest literary work in Elizabethan period. Drama not only teaches the morality, but also portrays the life of people. Every drama tells a problem. Drama can be tragedy which is full of sadness or can be comedy which is full of happiness. The structure of a drama usually begins with exposition, complication or climax, and denouement. Exposition is a stage for introducing a problem. Complication or climax is a stage where the problem becomes complicated. Finally, denouement is problem solving. These stages are usually arranged in some acts and scenes (Samekto, 1974:19). 
Drama can be divided into two types, namely classical drama and romantic drama. Classical drama depends on classic Greek conventions but romantic drama has its own standards. The main features of classical drama are the observance of what are called the three unities and the employment of the device of the chorus (Prasad, 1965:83-84). The three unities are as follows:

a. Unity of Time; it means that the time over which the plot is spread, and that occupied in its representation on the stage, should be the same or approximately the same.

b. Unity of Place; it means that the play must be confined to one place. The important events happened in other places usually will be informed by chorus.

c. Unity of Action; it means that the plot should either be purely tragic or purely comic but not a mixture of the two and no sub-plot Meanwhile, the chorus is the important element in classical drama which consists of a body of actors who make a report of what happened off the stage and to make such moral comments from time to time as would deepen the desired effect.

The dramatist in Elizabethan period is Christopher Marlowe. He makes four dramas which are known as the tragedy of Marlowesque. This tragedy tells about the tragic hero who is destroyed by his own power. The four dramas are Tamburlaine, Faustus, the Jew of Malta, and Edward II. The famous Marlowe's drama is Faustus which tells about a scientist named Dr. Faustus who wants to master all science. After mastering theology, philosophy, medical science, and law, he wants to learn magic. He must sacrifice his soul to the evil if he wants to learn magic. So, he is ready to give his soul to evil on the condition that during 24 years he will 
be given an absolute power, unlimited pleasure, and science. After the time is up, the evil comes to drag him to hell (Samekto, 1974:21).

Another famous dramatist in this period is William Shakespeare. $\mathrm{He}$ is the greatest dramatist in the world. Shakespeare was born in Stratford-on-Avon village in 1564. He studied in King Edward VI's Grammar School in Stratford. Then, he went to London. Between 1564 and 1613, he wrote at least 34 dramas. Shakespeare's drama can be divided into history, comedy, and tragedy. Some literary works produced by Shakespeare are as follows:

A. Histories

1. King Henry VI part II 1590-1

2. King Henry VI part III 1590-1

3. King Henry VI part I 1591-2

4. Richard III 1592-3

5. Richard II 1595-6

6. King John 1596-7

7. King Henry IV part I 1597-8

8. King Henry IV part II $1597-8$

9. King Henry V 1598-9

10. King Henry VIII 1612-13

B. Comedies

1. Comedy of Errors 1592-3

2. Taming of the Shrew 1593-4

3. Two Gentlemen of Verona 1594-5

4. Love's Labour's Lost 1594-5

5. Midsummer Night's Dream 1595-6

6. Merchant of Venice 1596-7

7. Much Ado About Nothing 1598-9

8. As You Like It 1599-1600

9. Twelfth Night 1599-1600

10. Merry Wives of Windsor 1600-1

11. Troilus and Cressida 1601-2

12. All's Well That Ends Well 1602-3

13. Measure for Measure 1604-5 
14. Pericles, Prince of Tyre 1608-9

15. Cymbeline 1609-10

16. Winter's Tale 1610-11

17. Tempest 1611-12

18. Two Noble Kinsmen 1612-13

C. Tragedies

1. Titus Andronicus 1593-4

2. Romeo and Juliet 1594-5

3. Julius Caesar 1599-1600

4. Hamlet, Prince of Denmark 1600-1

5. Othello 1604-5

6. King Lear 1605-6

7. Macbeth 1605-6

8. Antony and Cleopatra 1606-7

9. Coriolanus 1607-8

10. Timon of Athens $1607-8$

D. Poetry

1. A Lover's Complaint 1592

2. Venus and Adonis 1593

3. The Rape of Lucrece 1594

4. Sonnets 1595-1600

5. The Passionate Pilgrim 1599

6. The Phoenix and the Turtle 1600-1

There are some Shakespeare's works which are very famous in the world and some producers make them into a film. The works are as follows:

a. Julius Caesar

This is a tragic story. The central actor is Julius Caesar who is betrayed by his friends. He is stabbed by his own friends. Then, he makes a revenge for those who had stabbed him. At the end of the story, Julius Caesar shows up as a ghost and begins to kill his 
friends who have killed him. Finally, the ghost of Caesar can rest peacefully.

b. Romeo and Juliet

This is the famous story in the world. It tells about the love between Romeo and Juliet which is not approved by their families. Romeo's families forbid Romeo to fall in love with Juliet and Juliet's families also do the same thing. Their families try to separate Romeo and Juliet. Any attempt is tried to make them separate but their attempt is not successful because of the strength of their love. Finally, Romeo and Juliet make a plan. This plan is aimed to make their families accept the love between them. However, this plan is not successful. They both died because of their plan.

c. The Merchant of Venice

This story tells about a young man named Bassanio who wants to go to Belmont to propose a beautiful rich woman named Portia. Bassanio does not have much money to go to Belmont, so he asks his friend Antonio to give him money. Antonio is Bassanio's best friend. Antonio also does not have money, but he tries to get the money for Bassanio. Antonio comes to Shylock, a Jewish, to get a loan. Shylock gives Antonio his money on the condition that if Antonio cannot pay the loan on time, Antonio must give a pound of his flesh as a punishment. Finally, Bassanio goes to Belmont and he succeeds to get his girl Portia. However, as long as in Belmont, the time of Antonio's loan is over, and Antonio cannot pay the loan. So, Antonio must do the punishment given by Shylock. Bassanio heards this news and comes back to Venice immediately. Bassanio's wife disguises as a lawyer. She asks Shylock to cut 
Antonio's flesh without dropping any single blood, because it is not written in the agreement. However, it is impossible to do that. Finally, Antonio is free from the punishment and the story ends happily.

d. Hamlet

Hamlet was a prince of Denmark. His father was a king of Denmark. His father was poisoned by his uncle who wanted to be a king of Denmark. His uncle also wanted to marry Hamlet's mother. The ghost of Hamlet's father came to Hamlet and told the secret. Finally, Hamlet knew that his uncle was the murderer. Hamlet wanted to make revenge. Hamlet pretended to be crazy to prove the secret of his uncle. However, because of his act, he lost a woman whom he loved very much. At the end of the story, hamlet's plan was successful. His uncle died and his father can rest peacefully.

Beside Marlowe and Shakespeare, there is also a famous dramatist named Ben Jonson ( \pm 1573 - 1637). Although his works are not as much as Shakespeare, he has knowledge in classical culture and he is also a Poet Laureate (a poet appointed to the British Royal Household to write poems for special occasions). Ben Jonson is a comedy writer. He tries to use the concept of three unities in his works. The famous works of Ben Jonson are Volpone and The Alchemist. After reading Jonson's works, we can see that the characteristics in his works are not only imagination, but also the intellectual creation of the writer.

\section{Conclusion}

Literature in the true sense of term is that kind of writing which is charged with human interest, and characterized by permanence, colouring of imagination, and artistic embellishment. It deals with the life 
of man and his destinies on earth. It expresses thoughts, feelings, emotions, and attitudes towards life, which are permanent and universal. Human life experiences can be portrayed in any form of literary works such as poetry, drama, novel, etc. Those literary works develop as well as the development of civilization because literary works are the creation of human being and human being always develops every time. This condition can be seen in English Literature. From all period, Elizabethan period is regarded as the greatest development of English literature because it is characterized by abundance of production in branch of literature especially poetry and drama. The literary works of Elizabethan period are very famous and also can be found until now. In this period, there is a greatest dramatist in the world named William Shakespeare which has written some famous drama, namely Julius Caesar, The Merchant of Venice, Romeo and Juliet, Hamlet. Therefore, Elizabethan period is known as the golden age of English literature.

\section{Bibliography}

Abrams, M.H., et al. 1962. The Norton Anthology of English Literature. New York: Norton.

Alexander, Michael. 2000. A History of English Literature. New York: Palgrave.

Alexander, Peter. 1951. William Shakespeare, The Complete Works. London: Collins.

Baugh, Albert C. 1957. A History of the English Literature. New York: Appleton.

Departemen Pendidikan Nasional. 2005. Kamus Besar Bahasa Indonesia. Jakarta: Balai Pustaka.

Evans, Ifor. 1970. A Short History of English Literature. New York: Penguin Books.

Long, William J. 1950. English Literature. New York: Ginn. 
JADEs: Journal of Academia in English Education

Prasad, B. 1965. A Background to the Study of English Literature. India: Macmillan.

Samekto. 1974. Ikhtisar Sejarah Kesusasteraan Inggris. Jakarta: P.T. Gramedia.

Sinha, Manindranath. 1999. A Handbook of the Study of Literature. Bareilly: Prakash Book Depot.

Tilak, Raghukul. 1991. A Short History of English Literature. Bareilly: Prakash Book Depot.

Varghese, John \& Krishnaswamy, N. 2001. Contemporary Literary Theory: A Student's Companion. New Delhi: Macmillan India Limited.

Varshney. 1990. Literary Ages and Movements. Bareilly: Student Store. 